\title{
HR Practices and Employee Retention. Leader -Member Exchange (LMX) as a mediator
}

\author{
Vimala Kadiresan, Thangaraja Arumugam, Neeta Jayabalan, Hazrita Binti Ab Rahim, Charles \\ Ramendran SPR
}

\begin{abstract}
The present research aims at investigating the impact of human resource $(\mathrm{HR})$ practices on employee retention with the mediator effect of Leader-Member exchange (LMX) among IT employees in Malaysia. The present research attempts to narrow the research gaps by hypothesizing that HR practices (job security, work-life balance and training opportunities) significantly influence employee retention. The research employs a quantitative research approach whereby data were collected from 109 ICT professionals from MSC status companies in Malaysia. For analyzing the hypothesis, the SEM analysis is conducted. The research found that HR practices significantly influence employee retention among ICT professionals in Malaysia. It was also found that LMX mediates the relationship between HR practices and employee retention. Several implications from this research were discussed. In particular, HR managers, corporate leaders as well as government leaders and officials may use the findings of this research to justify the efforts in designing performance improvement interventions so that employee retention will be monitored and further enhanced among ICT professionals in Malaysia. Several other implications were further discussed.
\end{abstract}

Keywords: job security, worklife balance, training opportunities, human resource practices, leader member exchange, retention

\section{INTRODUCTION}

Employees retention issues have become a mainstream challenge to most of the organizations worldwide and continues to be the key concern for most of the employers especially in Malaysia regardless the sector, organization, or industry. In the current survey, retaining valuable employees was the significant concern for most of the organizations [1] Malaysia recorded the second highest involuntary turnover rate at $6.0 \%$ and third highest voluntary turnover rate at $9.5 \%$ in South East Asia in the year 2015. According to the report, three major aspects that possibly contribute to voluntary attrition are, employees pursuing higher education, better prospect, and work life balance [2]. One of the important industries in Malaysia that contributes to the economic growth is Information Technology (IT) industry.

Revised Manuscript Received on September 22, 2019.

Vimala Kadiresan*, HELP University, Selangor ,Malaysia vimala.k@help.edu.my

Thangaraja Arumugam, Vellore Institute of Technology, Chennai, Tamilnadu, India.

Neeta Jayabalan, Segi University,Kota Damansara, Petaling Jaya, Malaysia.

Hazrita Binti Ab Rahim, HELP University, Selangor ,Malaysia

Charles Ramendran SPR, University Tunku Abdul Rahman, Kampar,Perak, Malaysia.

\section{LITERATURE REVIEW AND HYPOTHESIS DEVELOPMENT}

\subsection{Human Resource Management Practices, LMX and Retention}

HRM can be explained as "all activities associated with the management of peoples in firms" [3] and these activities are mostly HR practices such as recruitment and selection, employee training and involvement and etc. HRM practices can be used by organizations to associate with employee's outcomes in terms of retention, effective commitment [4],[5]. In order to achieve the goals of an organization, HRM practices are proposed to increase the effectiveness of organization performance and to retain productive employees [6] as it helps employees to sustain their work related functions and to increase the effectiveness of organization performance [7].Many researchers have stated that an effective HRM practice is able to operate effectively and efficiently within a competitive environment [8].This has been supported by previous studies that effective HR practices has impacted the organizational success towards improving their strategies on employee retention by providing employees' with effective HR practices [9].

Employee retention is an issue faced by most of the organizations due to high turnover rate, meanwhile, it has become a significant challenge as different employees are motivated by different retention strategies [10]. One of the strategies found by [11] is that training and development, appraisal system and compensation are critical to employee retention. It implies that Human Resource Management plays a significant role in the organization as a retention strategy of employees. Therefore, this current study proposes that a good human resource management practice will result in positive employee retention behavior. Therefore, these three HR practices will be conducted in this research.

\section{i. Job Security}

Job security has been an important factor that contributes to employee performance, and encourage employees to stay in an organization [12]. It has been emphasized that job security is one of the main HRM practices that retain employees whilst enhance employees' performance and ability [13]. Similarly, [14] also stated that job security significantly affects employees' retention positively and is relevant to the reduction of turnover intention [15]. In addition, [16] have managed that employees who perceive a lower level job security tend to be more sensitive of the supports and resources

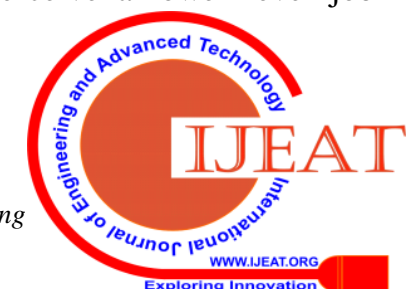


facilitated by their supervisors. To reduce the stressful situations, employees may pay more attention to acquire and retain job resources provided by the organization and/or the supervisors. [17] have defined LMX as establishing supervisory sponsorship which allows employees to venture into new opportunities in the organization. Employees with low-level job security may respond more positively to their constituted relationships with supervisors by performing better at work as well as conducting more altruistic behaviors.

\section{ii. Work-Life Balance}

According to [18] work life balance is the effectiveness of work environment that promotes better health and well-being, job security, job satisfaction, competency development and balance between work and non-work life. [19] have found that intervention of work demands into personal life (e.g. working during the weekend) leads to the heightened stress and emotional exhaustion among employees. This explain that work life balance is required by IT professionals with the aim to retain, motivate and gain leverage in recruiting the valuable IT employees. Hence, [20] indicates that work-life balance is increasingly important for employee retention. It is often found that LMX decreases the negative work-family overflows [21] LMX affects work-family through enhancing the significance of work [22] between supervisors and their subordinates.

\section{iii. Training Opportunities}

According to [11] employees will remain in the organisation if there is investment in training opportunities. This is because training maximizes employees' abilities to learn new skills, knowledge, attitudes and behaviors so as to sustain in variable circumstances [23]. Training equips employees to work effectively, hence employees become happy and satisfied with their work as they know what they are doing. Hence, keeping its employees motivated as well is a way to obtain positive organizational results [24]. When there is high LMX, leaders will train employees and teach them the knowledge that is required to help them grow and develop. When training opportunities are planned for employees, and a lot of knowledge and information is provided, it will lead to effective LMX [25]. As a result, employees will be more willing to develop close interpersonal relationships with their supervisor.

\subsection{Leader Member Exchange (LMX)}

LMX is defined as a interpersonal quality, trust and mutual obligation of a team member with his or her supervisor or manager [26]. LMX refers to the quality of the exchange relationship between employees and their superiors. It is based on the extent of emotional support and exchange of valued resources between supervisors and subordinates .Hence, both employees and leaders benefits [27][28]. It is highlighted that the establishment of work outcomes of LMX has been known widely in terms of employee wellbeing [29][30]. It was found that turnover intention was negatively linked with LMX [31]. Therefore, LMX is said to be associated with positive outcomes for employees and career success within an organization [27][32] It was proven that the outcomes of LMX is related to the behavior of a leader which comprises feedback and positive outcome. Thus, a positive quality of the LMX relationship is reciprocately postulated as employees in the organization are more comfortable with the leader's positive treatment [33] as this perception leads to supervisor being supportive towards employees. Since employees are being perceived as an essential indicator of HRM effectiveness [4]. Hence, this current study illustrates that an ideal human resource management practice will result in positive leader-member exchange.

\subsection{LMX as mediator}

LMX has played a mediating role in various studies [29][31][34].There is accordant finding in the leader-member exchange literature in which the employee's perception on the quality of the relationship is a great forecaster of work outcomes [35]. In accordance with this, hypothesis is formulated. So it is understood that human resource practice would influence employee retention and there is an impact when LMX mediates this relationship. Therefore, we hypothesize that: LMX mediates the relationship between HR practices (Job security, work life balance and Training opportunities) and employee retention.

\section{METHODOLOGY}

Data were collected from 109 employees from ICT companies in Malaysia. Overall, 200 questionnaires were distributed to participants and 109 were returned yielding a response rate of approximately 54.5 percent. The demographic profile includes the Males 68 percent of the sample and 77 percent was less than 35 years old. 51 percent of respondents are married. With respect to the work tenure, the great 72 percent of sample have worked for the present organisation less than 10 years. A five point likert scale is used in all the measurements in this study ( $1=$ Strongly disagree to 5=Strongly Agree).

\section{Table1: Descriptive statistics}

\begin{tabular}{lll}
\hline Variables & Mean & Std. Deviation \\
LMX & 3.14 & 1.236 \\
Retention & 3.41 & .955 \\
Job Security & 2.75 & .934 \\
Work Life Balance & 3.31 & 1.069 \\
Training Opportunities & 4.00 & .745 \\
\hline
\end{tabular}

Table1 denotes the mean and standard deviation of the variables. It is visible from the table that Training opportunities are high positive by the respondents $(\overline{\mathrm{x}}=4, \sigma=.74)$. Job security is negatively agreed by the respondents $(\overline{\mathrm{x}}=2.75, \sigma=.93)$. With regards to normality (Hair, Black, Babin, Anderson, \&Tatham, 2012), the distribution values lie between +2 to -2 of skewness and +3 to -3 kurtosis which shows the normal data for the Inter-correlation. 


\begin{tabular}{|c|c|c|c|c|c|}
\hline LMX & $\sum_{1}^{X}$ & 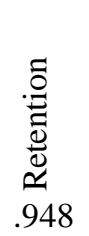 & $\begin{array}{l}\stackrel{\gtrsim}{\Xi} \\
\stackrel{0}{0} \\
\stackrel{D}{D} \\
\stackrel{0}{\circ} \\
.639\end{array}$ & 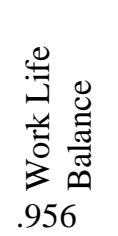 & 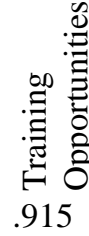 \\
\hline Retention & .948 & 1 & .635 & .925 & .859 \\
\hline Job Security & .639 & .635 & 1 & .606 & .492 \\
\hline $\begin{array}{l}\text { Work Life } \\
\text { Balance }\end{array}$ & .956 & .925 & .606 & 1 & .930 \\
\hline $\begin{array}{l}\text { Training } \\
\text { Opportunities }\end{array}$ & .915 & .859 & .492 & .930 & 1 \\
\hline \multirow{3}{*}{\multicolumn{2}{|c|}{$\begin{array}{l}\text { Reliability coefficient } \\
\text { for items } 5\end{array}$}} & \multicolumn{2}{|c|}{ Alpha } & & .945 \\
\hline & & \multicolumn{4}{|c|}{ Standardized Item } \\
\hline & & \multicolumn{3}{|c|}{ Alpha } & .9 \\
\hline
\end{tabular}

Inter correlations between all variables in the study were conducted. On the off chance that the majority of the things are estimating a similar idea, we would anticipate that all of them should relate well together. Reliably low relationships over the board should be expelled from the survey to make it progressively solid. All the variables are highly correlated but job security and training opportunities $(\rho=.492)$ reflect low correlation.

\section{Instrument validation}

Cronbach's alpha reliability coefficient normally ranges between 0 and 1 . However, there is actually no lower limit to the coefficient. The closer Cronbach's alpha coefficient is to 1.0 the greater the internal consistency of the items in the scale. As per rules of thumb of [36] the items in the study portrays an excellent level of internal consistency (.945)

Table 3: Human Resource practices construct reliability

instruments for further structural equation modelling. From the output, the human resource practices latent variable has got the excellent construct validity $(\mathrm{CR}=0.894)$.

\section{RESULT AND FINDINGS}

\section{Structural equation modeling}

For analyzing the hypothesis, the SEM analysis is conducted. The mediating role of LMX on the relationship of human resource practices and employee retention. The independent variable and dependent variable is mediated by LMX when it shows the indirect significant relationship. The independent variables are job security, work life balance and training opportunities which are denoted by a latent variable which is the Human resource practice, The dependent variable is employee retention and the LMX is the mediator. A measurement model has been developed to analyse the relationship effects and measure the mediation level of LMX. In order to check the structural relationships, the following hypothesis have been formulated.

H1: There is a relationship between HR Practices and LMX.

$\mathrm{H} 2$ : There is a relationship between HR Practices and employee retention.

H3: There is a relationship between LMX and Retention.

H4: LMX mediates the relationship between HR practices (Job security, work life balance and Training opportunities) and employee retention.

\section{H1: There is a relationship between HR Practices and LMX.}

The relationship between the HR practices and LMX is statistically significant with a regression coefficient of 1.712 $(\mathrm{P}<0)$ the alternate hypothesis as formulated is accepted. The HR practices influence the LMX positively. When employees are provided with job security, work life balance and training opportunities, it clearly stimulates the LMX relationships. In support of this argument, the study of [37] opined that superiors who directly monitor and supervise employees, pose a pivotal role in crafting the sub-ordinate evaluation whilst addressing core HRM practices. Similarly, [38] explained that the right essence of human resource management practices such as training and development will reflect on the behavior of supervisors and employee management.

Variables

Training Human

Opportun Resource

ities Practices

Work Human

$\begin{array}{lllll}\text { Life } & \text { Resource } & .98 & 0.97 & 0.02\end{array}$

Balance Practices
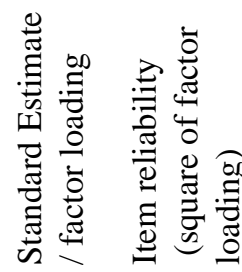

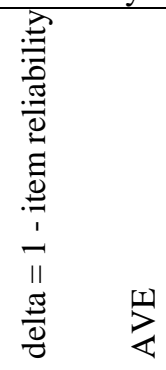

Job

Security

Human

Resource

Practices

$\begin{array}{lll}.61 & 0.37 \quad 0.62\end{array}$

\section{H2: There is a relationship between HR Practices and} employee retention

The relationship between HR Practices and employee retention is statistically significant with the regression coefficient of .349(0.02<.05). Therefore, the alternate hypothesis is accepted. This finding is in line with the previous studies where researchers found positive 0.740 .8 relationship between HR practices and retention [6][7]. Hence, one can vouch that HR practices such as job security, worklife balance and training opportunities can influence employee retention among the ICT professionals.

\section{H3: There is a relationship between LMX and Retention.}

The relationship between LMX and Retention is statistically significant with the regression estimate of $.540 \quad(\mathrm{P}>0)$. The alternate hypothesis is accepted. 
Employee decisions to remain with their job are mostly influenced by the leader as LMX plays a major role in facilitating the retention of the employee by exhibiting trust, obligation and respect. LMX gets to facilitate the accomplishment of work goals and stimulation of personal development. These reasons can be valid enough to give organization an ability to retain its employees. This is supported [39] where LMX plays a significant role in the motivation of employees which determines the workplace outcomes [32] in turn retaining the employees [38]. Thus, it can be concluded that the general understanding of a well-treated employee is that he or she shall project loyalty and serve longer in the organization as a projection of appreciation towards the supervisors and the organization.

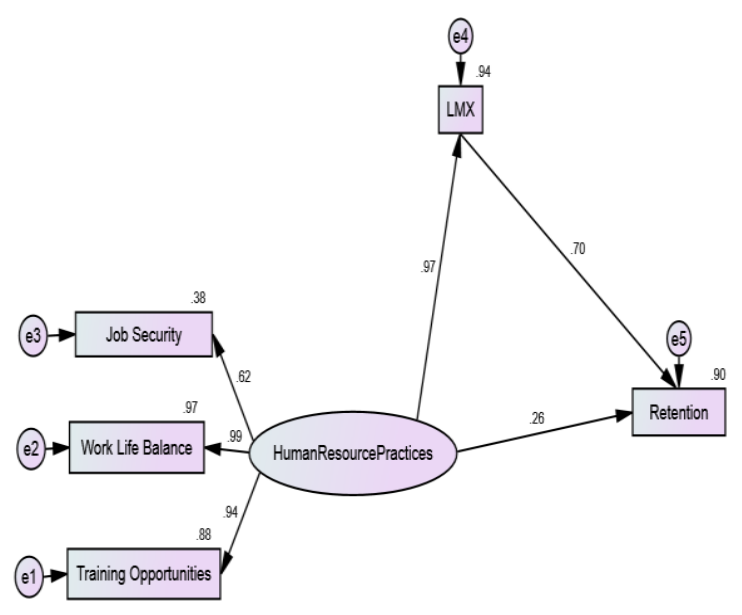

Figure 1: Structural Equation Modelling: Human resource practices and its effect on retention

Table 4: Regression Weights:

\begin{tabular}{|c|c|c|c|c|}
\hline $\begin{array}{c}\text { Dependent } \\
\text { Variables }\end{array}$ & $\begin{array}{c}\text { Independent } \\
\text { Variable }\end{array}$ & Estimate & S.E. & C.R. \\
\hline LMX & $\begin{array}{l}\text { Human } \\
\text { Resource } \\
\text { Practices }\end{array}$ & 1.712 & $\begin{array}{c}.07 \\
4\end{array}$ & $\begin{array}{c}23.24 \\
2\end{array}$ \\
\hline Retention & LMX & .540 & $\begin{array}{c}.11 \\
5\end{array}$ & 4.702 \\
\hline Retention & $\begin{array}{l}\text { Human } \\
\text { Resource } \\
\text { Practices }\end{array}$ & .349 & $\begin{array}{c}.20 \\
5\end{array}$ & 1.707 \\
\hline
\end{tabular}

The model shows a good fit with the CMIN/DF $=3.23$, GFI $=.919, \mathrm{CFI}=.974$, RMSEA $=0.022$. The result denotes that the model would predict the sequential effects of the constructs of Human resource practices and retention. The following table has derived the regression output of the variable.

\begin{tabular}{ccc} 
& Human Resource Practices & LMX \\
LMX & 0.97 & 0 \\
Retention & 0.935 & 0.7 \\
\hline
\end{tabular}

Table 4 depicts the result of the regression. The standardized estimate, standard error, critical ratio and $p$ value would predict the statistical position of the relationships.

\section{Mediation effect}

H4: LMX mediates the relationship between HR practices (Job security, work life balance and Training opportunities) and employee retention

\section{Standardized Direct Effects (Group number 1 - Default model)}

\begin{tabular}{lcc}
\hline & Human Resource Practices & LMX \\
LMX & .000 & .000 \\
Retention & .679 & .000 \\
\hline
\end{tabular}

Standardized Indirect Effects (Group number 1 - Default model)

\begin{tabular}{lcr}
\hline & Human Resource Practices & LMX \\
LMX & .970 & .000 \\
Retention & .256 & .700
\end{tabular}

From the analysis of mediation, researcher measures the total, direct and indirect effects between Human Resources Practices, on Retention, while LMX acts as a mediator. The result shows the direct effect of Human Resources Practices have a positive effect on Retention. I.e. Human Resources Practices is increased by 1 standard deviation, Retention is increased by 0.256 . Modifications in the influence on Human Resources Practices while LMX act as mediator. The result shows the indirect effect of Human Resources Practices has a positive effect on Retention through LMX. i.e. Human Resources Practices is increased by 1 standard deviation, Retention increase by 0.925 . From the result, it is clear that there is a support for the hypotheses of mediation. The alternative hypothesis on mediation effect "LMX mediates the relationship between HR practices (Job security, work life balance and Training opportunities) and employee retention" is accepted. This is similar to previous studies that support LMX as a mediator in fostering work outcomes [29] [31],[34] .Employees may build a platform to strengthen professional qevelopment when LMX is applied in the job environment that enables motivation in job processes [40].

$* * *$

\section{CONCLUSION}

This study attempts to analyse the mediating role of Leader * member exchange on the various relationships. The model developed shows acceptable model fit and LMX depicts an influential mediational effect with respect to HR practices on employee retention. A leader can influence an employee in terms of Job security, training opportunities and Work life balance and get favourable outcome for retention. The study reveals that in spite of good HR Practices, a good leadership is essential for the retention of employees. LMX plays a vital role in employee retention. The results of this study is very timely to support the growth of the ICT industry especially with the rapid growth of the digital sector. With the emergence of the Artificial Intelligence, Augmented Reality and Virtual Reality era, Sustainable Development Goals themes by the United Nations and Fourth Industrial Revolution, the LMX poses as an essential formula to ensure continuous growth in relevant organizations. Policy makers and conglomerate corporate companies should revisit their missions and visions to 
incorporate the LMX in their way forward.

\section{REFERENCES}

1. JobStreet.com (Feb 2016), Hiring Demand Improves in Q1 2016 Despite Key Concerns. Retrieved Feb 17, 2016 from http://www.jobstreet.com.my/career-resources/hiring-demand-

2. HR in Asia (Dec 2015), Key Insights to Attract, Reward and Retain Talent in Malaysia: Aon Hewitt's Views. Retrieved Dec, 32015 from http://www.hrinasia.com/recruitment/key-insights-to-attract-reward-an d-retain-talent-in-malaysia-aon-hewitts-views/ 29.

3. Malaysia Digital Economy Corporation Snd Bhd. (2017) Retrieved from https://www.mdec.my/mscapplication/

4. Boxall, P. and Purcell, P. (2008) ' Strategy and Human Resource Management, 2nd ed.,Palgrave Macmillan, Basingstoke.

5. Veth, K. N., Korzilius, H. P., Van der Heijden, B. I., Emans, B. J., \& De Lange, A. H. (2017). Which HRM practices enhance employee outcomes at work across the life-span?. The International Journal of Human Resource 1-32.https://doi.org/10.1080/09585192.2017.1340322

6. Kadiresan, V., Kamil, N. M., Mazlan, M. R. M., Musah, M. B., \& Selamat, M. H. (2016). The Influence of Human Resource Practices on Employee Retention: A Case Study. International Journal of Human Resource Studies, 6(3), 122-148

7. Kadiresan, V., Selamat, M. H. B., Ramendran, S. P. R., \& Parasuraman, B. (2018). Human Resource Practices and Retention: Academicians Perspective. Advanced Science Letters, 24(7), 4857-4860. https://doi.org/10.1166/asl.2018.11217

8. Pfeffer, J., \& Veiga, F. (1999) 'Putting People First for Organizational Success', Academy of Management Executive,, 13(2), pp. 37-48.

9. Obeidat, B., R., Masa'deh, R., \& Abdallah, A. (2014). The Relationships among Human Resource Management Practices, Organizational Commitment, and Knowledge Management Processes: A Structural Equation Modeling Approach. International Journal of Business and Management, vol. 9. No 3.;2014

10. Kadiresan.V, Mehrunishah B.B.H, Mohamad H.S, Jayabalan.N, Mansori.S (2016) "HR Practices and organizational commitment among SME employees which leads to retention". Proceedings of the 2016 International Conference on Industrial Engineering and Operations Management, Kuala Lumpur, Malaysia, March 8-10, 2016

11. Milman, A., \& Dickson, D. (2014) 'Employment characteristics and retention predictors among hourly employees in large US theme parks and attractions. ', International Journal of Contemporary Hospitality Management, 26(3), pp. 447-469.62.

12. Hong, E. N. C., Hao, L. Z., Kumar, R., Ramendran, C., \& Kadiresan, V. (2012). An effectiveness of human resource management practices on employee retention in institute of higher learning: A regression analysis. International journal of business research and management, 3(2), 60-79.

13. Purohit, B., \& Bandyopadhyay, T. (2014). Beyond job security and money: driving factors of LMX for government doctors in India. Human Resources for Health, 12(1), 12. Beyond job security and money: Driving factors of LMX for government doctors in India. Hum Resource Health. 2014; 12(1):12

14. Conklin, M. H., \& Desselle, S. P. (2007). Job Turnover Intentions among Pharmacy Faculty. American Journal of Pharmaceutical Education, 71(4),1-9.

15. Parnell, J. A., \& Crandall, W. R. (2003). Propensity for participative decision making, job satisfaction, organizational commitment, organizational citizenship behaviors and intention to leave among Egyptian managers. The Multinational Business review, 11(1), 45-65.

16. Hsu, M. K., Jiang, J. J., Klein, G., and Tang, Z. (2003) 'Perceived Career Incentives and Intent to Leave,', Information \& Management , 40(5), pp. 361-369.

17. Loi, R., Ngo, H. Y., Zhang, L., \& Lau, V. P. (2011). The interaction between leader-member exchange and perceived job security in predicting employee altruism and work performance. Journal of Occupational and Organizational Psychology,84(4), 669-685. https://doi.org/10.1348/096317910X510468

18. Sparrowe, R.T. and Liden, R.C., (1997). Process and structure in leader-member exchange. Academy of management Review, 22(2), pp.522-552.

19. Rethinam, G. S., \& Ismail, M. (2008). Constructs Of Quality Of Work Life: A Perspective Of Information Technology Professionals. European journal of social sciences, 1 .
20. Hyman, J. and Summers, J., (2004). Lacking balance? Work-life employment practices in the modern economy. Personnel Review, 33(4), pp.418-429

21. Das, B.L. and Baruah, M., (2013). Employee retention: a review of literature. Journal of Business and Management, 14 pp.8-16.Department Of Statistic Official portal, Malaysia. (2017). Retrieved From https://www.dosm.gov.my/v1/index.php?r=colmn/cthemeByCat\&cat= 319\&bul_id=MjhtcEV6dGFSOGc3NnEwaytRUkhTUT09\&menu_id= TE5CRUZCblh4ZTZMODZIbmk2aWRRQT09

22. Major, D.A. and Lauzun, H.M. (2010) 'Equipping Managers to Assist Employees in Addressing Work-Family Conflict: Applying the Research Literature toward Innovative Practice', The Psychologist-Manager Journal, 13(2), pp. 69-85.

23. Hackman, J.R., and Oldham, G.R. (1976) 'LMX through the design of work: Test of a theory', Organizational Behavior and Human Performance, 16(2), pp. 250-279.

24. Armache, J. (2014). Ways and means to keep employees motivated, productive, and loyal. Journal of International Diversity, 2014(2), 87-103.

25. Joung, H.-W., E.-K. Choi, \& B.K. Goh, (2010) 'Training LMX factors as perdictors of employees' training satisfaction in Foodservice Operation.', Paper presented at the 2010 International CHRIE Conference- Refereed Track, San Juan,. Puerto Rico.

26. Graen, G. B. and Uhl-Bien, M. (1995), "Relationship-Based Approach to Leadership: Development of Leader-Member-Exchange (LMX) Theory of Leadership Over 25 Years: Applying a Multi-Level Multi-Domain Perspective", Leadership Quarterly, Vol. 6 No. 2, pp. 219-247.

27. Brunetto, Y., Shacklock, K., Teo, S., \& Farr-Wharton, R. (2014), “The impact of management on the engagement and well-being of high emotional labour employees", The International Journal of Human Resource Management, 25: 2345-2363.

28. Atitumpong, A., \& Badir, Y. F. (2018). Leader-member exchange, learning orientation and innovative work behavior", Journal of Workplace Learning, Vol. 30 Issue: 1, pp.32-47, https://doi.org/10.1108/JWL-01-2017-0005

29. Sutcliffe, K. M., Vogus, T. J., \& Dane, E. (2016). Mindfulness in organizations. Annual Review of Organizational Psychology and Organizational Behavior, 3(1), 55-81. doi:10.1146/annurev-orgpsych-041015-062531

30. Ibrahim, R. M. (2014). The link between leader-member exchange, organizational citizenship behavior and job satisfaction: A case study on local government. International Journal of Academic Research in Business and Social Sciences, 4(5), 313.

31. Adil, M. S., \& bin Ab Hamid, K. (2017). Impact of individual feelings of energy on creative work involvement: A mediating role of leader-member exchange. Journal of Management Sciences, 4(1) 82-105

32. Marstand, A. F., Martin, R., \& Epitropaki, O. (2017). Complementary person-supervisor fit: An investigation of supplies-values (SV) fit, leader-member exchange (LMX) and work outcomes. The Leadership Quarterly, 28(3), 418-437.

33. Raghuram, S., Gajendran, R. S., Liu, X., \& Somaya, D. (2017) Boundaryless LMX: Examining LMX's impact on external career outcomes and alumni goodwill. Personnel Psychology, 70(2), 399-428

34. Dulebohn, J. H., Bommer, W. H., Liden, R. C., Brouer, R. L., \& Ferris, G. R. (2012). A MetaAnalysis of Antecedents and Consequences of Leader-Member Exchange: Integrating the Past with an Eye toward the Future. Journal of Management, 38, 1715-1759, DOI $10.1177 / 0149206311415280$.

\section{AUTHOR'S PROFILE}

Vimala Kadiresan*, HELP University, Selangor ,Malaysia. The area of research includes, Management. Human Resource Management, Training and Development.

Thangaraja Arumugam, Vellore Institute of Technology, Chennai, Tamilnadu, India.

Neeta Jayabalan, Segi University,Kota Damansara, Petaling Jaya, Malaysia.

Hazrita Binti Ab Rahim, HELP University, Selangor ,Malaysia

Charles Ramendran SPR, University Tunku Abdul Rahman Kampar,Perak, Malaysia. 